\title{
A Study on Postgraduate Curriculum Group of Vehicle Engineering in Local Colleges Under the Background of New Engineering Section
}

\author{
Lan TANG, Xiao-feng YIN, Yan-hai XU \\ Chong CHEN and Yan-qiong TENG
}

Xihua University, Chengdu, Sichuan, China

\begin{abstract}
Keywords: New Engineering; Automotive Engineering; Local Colleges; Master Degree Candidate; Curriculum Group.
\end{abstract}

\begin{abstract}
This article gives an overview of the connotations of the new engineering section, analyzes the characteristics of postgraduate course settings in local colleges and points out the problems that existing in the current curriculums. Then it proposes a plan for setting up a postgraduate course groups for vehicle engineering under the background of new engineering background, as well as training methods for improving the engineering ability of a master degree candidate for a automotive engineering major through cross-discipline course selection, dualacademic professors and innovative practice bases.
\end{abstract}

\section{Introduction}

Postgraduates are the reserve forces of national scientific innovation, in order to actively respond to the new round of scientific revolution and industry information changes and support service innovation to drive development, a series of national strategies such as "Made in China 2025" and a new economy represented by new technologies, new formats, new models and new industries are flourish which put a higher request to auto-engineering technology talents at the same time, this need us to accelerate the reform and innovation of postgraduate engineering education urgently. So as to achieve this goal, under the shortage of finance and experimental devices, local college must strive to improve the training level of automotive engineering postgraduates by setting the specialized curriculum group. There are many factors that affect the training level of postgraduates, but the most important factor, undoubtedly, is the setting of curriculum group.

\section{"New Engineering" Overview}

Higher engineering education is an important part of our national higher education. Thus, deepen the reform of engineering education, and construct a powerful country for engineering education are great significant to serve and support our national economic transformation and upgrading. This need us to push the construction of "new engineering", attach the importance in artificial intelligence (AI) which integrate with discipline professional education such as computer, control, math, statistics, physics, medicine, biology, sociology, law, form "AI+X" mode of composite professional training. By 2020, the number of "AI+X" composite special major will reach 100, and the institute of AI, research institute or integrated research center will reach 50 . Deepen the integration of industry-education, university-enterprise cooperation and collaborative education to promote the transformation and upgrading of traditional engineering majors and carry out research and practice of new engineering in local colleges and universities.

\section{The Setting of Curriculum Group of Automotive Engineering}

The training goal of automotive engineering majors in local colleges and universities are: students can systematically master basic scientific knowledge that involve in the field of automotive engineering, have a broader knowledge of basic technology, and possess the necessary professional knowledge and basic skill of design, manufacture, electric automatic control of automobiles and 
relevant products, have a strong ability of engineering practice and a certain degree of innovative spirits, and become the practical senior engineer who can work on design, manufacture, test, application research, marketing in automotive engineering field.

Based on the training scheme and training target of automotive engineering postgraduate, the setting of automotive engineering curriculums mainly include: degree courses, optional courses and compulsory courses. Degree courses can be divided into three parts: public basic courses, discipline basic courses and practical teaching courses. Public basic courses include: theory and practice of socialism with Chinese characteristics, Dialectics of nature, English, Chinese and foreign paper writing, Numerical Computation method. Discipline basic courses include: professional foreign languages, automotive control theory, automotive testing technology and signal analysis, combustion and control of automotive engine, automotive vibration, operations research, safety engineering of road traffic, modern car and transportation of automobile, graph theory and application, advanced manufacture technology, data structure and programming, modern mechanical manufacturing theory, the principle and application of CAD/CAE. Practical teaching courses mainly include: product development practice and field investigation practice. Optional courses are divided into education for all-around development and discipline-orientation course. Education for all-around development include: public optional courses (language, computer, gym, management, economy, law and art and so on) and interdisciplinary major courses. Disciplineorientation courses include: optimal control applications \& methods, database technology, finite element application technology, automotive electronic control technique, fault diagnosis expert system, automobile noise analysis and control, reliability analysis, automotive engine experimental technique, gas engine technique, internal combustion engine twin power, vehicle fuel and lubricating oil, automotive engine electronic control technique, automotive tire, automotive dynamics, automotive ergonomics, automobile automatic transmission theory and control technique, transportation plan and design, modern logistics, the system analysis and optimizing of logistics, traffic control engineering, traffic engineering overview. Compulsory courses mainly include: mid-term examination, Master-Degree proposal, social practice, academic activities and academic achievements.

According to the curriculum setting presented above, it can be seen that the curriculums refer to the most of traditional compulsory courses of automotive engineering. However, for the emerging technology that involve in the automotive field, there are no systematic setting of corresponding courses. The setting of postgraduate curriculums lags behind the development of new fields in automotive engineering. It's cannot or say that we are not sensitive enough to academic innovation, the response is slow, and we are even less able to achieve the target of training emerging engineering scientific talents.

\section{The Setting of Automotive Engineering Postgraduates Curriculum under the New Engineering Background}

The establishment of compulsory courses for postgraduates in automotive engineering is very important to the cultivation of postgraduates in this discipline. But each college has its own opinion on this matter. At present, to sum up, they can be conclude into the following five main points and plans in domestic.

1) The first opinion: compulsory courses must be set according to the fist class discipline, attach the importance in "general knowledge", and cultivate knowledgeable versatile talents.

2) The second opinion: students should have more right in choosing courses, the compulsory courses have less requirement, most of foreign colleges take this method. (In fact, every supervisor will put forward kinds of requirements to their students.)

3) The third opinion: attach the importance in the state of theoretical courses, two-thirds of the compulsory courses are based on theoretical courses.

4) The forth opinion: determine two to three required course according to the first-level discipline first, then determine some compulsory courses according to the second class.

5) The fifth opinion: setting subject compulsory courses according to the second class totally. 
We should commit upper five opinions or plans are reasonable, but they have some shortcomings too. Although the external forms may look different, the internal starting points are similar in many aspects. From a practical point of view, postgraduates in the field of automotive engineering should have some basic training, if they don't even have the basic knowledge and abilities, they cannot be called postgraduates in the discipline of automotive engineering. Thus, it's necessary to set up some basic courses within the scope of first-level discipline.

Since February 2017, the ministry of education has actively promoted the construction of new engineering disciplines and successively formed "Fudan Consensus", "Tianda Actions" and "Beijing Guide". "Tianda Actions" points out that we should strive to develop new technologies such as big data, cloud calculation, Internet application, AI, virtual reality, gene engineering, nuclear engineering and intelligent manufacturing, integrated circuit, oceanography, biological medicine, new material. Industrial-related emerging engineering specialties and distinctive professional clusters. Update and reform traditional subject majors, service for mining, iron, petrifaction, mechanical engineering, light industry, textile and so on finish transformation and upgrading, then develop highly towards value chain. It promotes the cross-combination of existing engineering disciplines, cross-convergence of engineering and other disciplines, extension of applied sciences to engineering disciplines, and fostering the development of new cross-disciplinary disciplines. Under the background of new engineering, the setting of automotive engineering postgraduates curriculum should have some changes, taking into account factors such as student interest and the research direction of the supervisors, it is possible to adopt some basic courses, and then choose the training plans to courses are according to the projects of the supervisor and interests of students. Both basic training and in-depth research on emerging technologies can be achieved to achieve the renewal of traditional disciplines.

At present, the hot researches fields of auto researches are driverless car and new energy vehicles, driverless car technologies and new energy auto technologies involve battery, bio-fuel, computer and other subjects, apart from traditional mechanical engineering, electrical machinery, hydraulic pressure, control. Automotive engineering postgraduates not only need to master necessary professional knowledge, but also need to supplement knowledge in project management and other aspects of knowledge. Thus, the colleges adopt the method of "dual-academic professors", co-cultivation with the school of mechanical engineering, the school of material science and engineering, the school of computer and software engineering, the school of management, the school of electrical and electronic information, practice interdisciplinary courses. Take the driverless car as example, driverless cars that mainly refer to the major fields are: route planning, environmental perception and intelligent control. The environment perception is mainly the perception of surrounding road conditions by machine vision, thus we can establish picture processing, machine study, deep learning and road planning and other relevant courses to meet the needs of students' specialized knowledge requirement.

\section{Conclusion}

Under the background of new engineering, in our country, automotive engineering science is stepping in a new historical period. Although the current postgraduates' hardware and software facilities in local colleges and universities still have a large gap compared with two first-rate institutions, we must have a strong faith to improve the setting of postgraduates curriculum groups and teaching patterns based on our efforts to improve ourselves, then reach the purpose of improving teaching efficiency and perfecting postgraduate training segment.

\section{Acknowledgement}

With the help of postgraduate education teaching reform project of Xihua University (YJG2016006), teachers support program of Xihua University (21050018), postgraduate education reform and innovation project of Sichuan province (SJG2014005), research and project on the reform of the training model of innovative engineering of automotive engineering postgraduates 
under the background of engineering certification, we finish this paper more smoothly. Thanks a lot.

\section{References}

[1] Zhu Z., etc., Research on the practical teaching system of vehicle engineering [J]. China Management Information Technology 2017, 20 (10): 235-236.

[2] Xu W., Li M. Y., Wang Z. B., Research Course System and Talent Training Model of Vehicle Engineering [J]. Heilongjiang Education: Higher Education Research and Evaluation, 2008 (12): 28-30.

[3] Yang X. H., Fu L. J., Li Z. H., Exploration of Teaching Content Reform and Teaching Methods for "Vehicle Electronic Control" for Postgraduate Course. Academic Journal (first edition), 2011 (12): 102-103.

[4] Jiang Y. F., Wu J. H., Research Course System and Talent Training Model of Vehicle Engineering [J]. Agricultural Machinery of the Age, 2017 (9): 243-243. 